DOI: https://doi.org/10.15407/techned2019.05.010

\title{
STOCHASTIC TRANSITION PROCESSES IN THE CIRCUITS OF THE DISCHARGE PULSES SHAPER, OPERATING FOR ELECTRIC SPARK LOAD
}

Journal

Publisher

ISSN

Issue

Pages
Tekhnichna elektrodynamika

Institute of Electrodynamics National Academy of Science of Ukraine 1607-7970 (print), 2218-1903 (online)

No 5, 2019 (September/Oktober)

$10-16$

\begin{abstract}
Author
N.I. Suprunovska*

Institute of Electrodynamics National Academy of Sciences of Ukraine, pr. Peremohy, 56, Kyiv, 03057, Ukraine,

e-mail: iednat1@gmail.com

* ORCID ID : http://orcid.org/0000-0001-7499-9142
\end{abstract}

\begin{abstract}
An approach to the analysis of sequences of interrelated transient processes in the circuits of the discharge pulse shaper, the discharge circuit of which contains an electric-spark load with a stochastically varying active resistance, is proposed. Such load resistance is characterized by a continuous random variable with an arbitrary probability distribution (uniform, normal, or other less common distribution). The proposed approach is focused on the analysis of transient processes in circuits with variable structure, in which there is a repeating sequence of interrelated transients at stochastic change in one of the circuit parameters (for example, load resistance) in a certain continuous range. It is proposed a modification of the method of difference equations, which allows to convert the stochastic difference equation for the desired electrical characteristic of a circuit into deterministic difference equations for the expectation and variance of the desired characteristic. As an example, a transient process in a second-order circuit with a stochastic load, having a continuous uniform distribution, was considered. An analytical expression for the mathematical expectation of the capacitor voltage was obtained. $\mathrm{R}$ eferences 17, figures 5 .
\end{abstract}


Key words: transients, capacitor charge, capacitor discharge, stochastic load, random process, probabilistic properties, continuous probability distribution.

Received: 23.04.2019

Accepted: 06.05.2019

Published: 01.08.2019

\section{References}

1. Sen B., Kiyawat N., Singh P.K., Mitra S., Ye J.H., Purkait P. Developments in electric power supply configurations for electrical-discharge-machining (EDM). Proc. 5th International Conference on Power Electronics and Drive Systems , 2003. PEDS 2003. Singapure, 17-20 November 2003. Vol. 1. Pp. 659-664.

2. Shcherba A.A., Suprunovska N.I. Electric Energy Loss at Energy Exchange Between Capacitors as Function of Their Initial Voltages and Capacitances Ratio. Tekhnichna Electrodynamika.

2016. No 3. Pp. 9-11. DOI:

https://doi.org/10.15404/techned2016.03.009

3. Beletsky O.A., Suprunovska N.I., Shcherba A.A. Dependences of power characteristics of circuit at charge of supercapacitors on their initial and final voltages. Tekhnichna

Elektrodynamika

1. Pp. 3-10. (Ukr) DOI:

https://doi.org/10.15404/techned2016.01.003

4. Casanueva R., Azcondo F.J, Branas C., Bracho S. Analysis, design and experimental results of a high-frequ-ency power supply for spark erosion. IEEE Transactions on Power Electronics. 2005. Vol. 20. Pp. 361-369.

DOI:

https://doi.org/10.1109/TPEL.2004.842992

5. Nguyen P.K., Lee K.H., Kim S.I., Ahn K.A., Chen L.H., Lee S.M., Chen R.K., Jin S., Berkowitz A.E. Spark Erosion: a High Production Rate Method for Producing Bi0.5Sb1.5Te3 Nanoparticles With Enhanced Thermoelectric Performance. Nanotechnology. 2012. Vol. 23. Pp. 415604-1 415604-7.

DOI: https://doi.org/1

$\underline{0.1088 / 0957-4484 / 23 / 41 / 415604}$

6. Nguyen, P.K., Sungho J., Berkowitz A.E. MnBi particles with high energy density made by spark erosion. J. Appl. Phys. 2014. Vol. 115. Iss. 17. Pp. 17A756-1. DOI: https://doi.org/10.106 $\underline{3 / 1.4868330}$

7. Shydlovska N.A., Zakharchenko S.M., Cherkassky O.P. The analysis of electromagnetic processes in output circuit of the generator of discharge pulses with non-linear model of plasma-erosive load at change their parameters in wide ranges. Tekhnichna Elektrodynamika. 
2016. No 1. Pp. 87-95. (Rus) DOI:

https://doi.org/10.15407/techned2016.01.087

8. Ivashchenko D.S., Suprunovska N.I. Transients in circuits with stochastic load, which characterized by continuous random variable. Tekhnichna Elektrodynamika. 2016. No 4. Pp. 17-19. (Rus) DOl:

https://doi.org/10.15407/techned2016.04.017

9. Suprunovska N.I., Ivashchenko D.S. Multilevel model of interdependent transients in circuits of electro-discharge installations with stochastic load. Tekhnichna Elektrodynamika. 2013. No 5. Pp. 5-13. (Rus)

10. Ventsel E.S., Ovcharov L.A. Probability theory and its engineering applications. Moskva: Vysshaia shkola, 2000. 480 p. (Rus)

11. Kashyap R.L., Rao A.R. Construction of dynamic stochastic models based on experimental data. Moskva: Nauka. Glavnaia redaktsiia fiziko-matematicheskoi literatury, 1983. 384 p. (Rus) 12. Lisyev V.P. Probability theory and the mathematical statistics. Moskva: MESI, 2006. 199 p. (Rus)

13. Volkov I.V., Vakulenko V.M. Sources of power lasers. Kiev: Tekhnika, 1976. 174 p. (Rus) 14. Shcherba A.A., Suprunovska N.I., Ivashchenko D.S. Determination of probabilistic properties of electrical characteristics of circuits of electric discharge installations taking into acount their stochastically changing parameters. Tekhnichna Elektrodynamika. 2019. No 4. Pp. 3-11. (Rus) DOI:

https://doi.org/10.15407/techned2019.04.003

15. Zhuikov V.Ya., Suchik V.E. Methods for analysis of circuits of rectifier converters with variable structure and any influencing sources by method of difference equations. Kiev: Kievskii Politekhnicheskii Institut, 1982. 47 p. (Rus)

16. Romanko V.K. Difference equations. Moskva: Binom, 2006. 112 p. (Rus)

17. Veksler G.S. Power supply of special equipment. Kiev: Vyshcha shkola, 1975. 431 p. (Rus) 